\title{
Planlanmış Davranış Teorisi ile Yerli Y Kuşağı Turistlerin Destinasyon Tercih Etme Niyetlerinin Belirlenmesi*
}

\section{Explaining the Local Y Generation Tourists' Intentions of Preferring a Destination Using the Planned Behavior Theory}

\author{
Dr. Öğr. Üyesi Ayşegül KUTLUK BOZKURT ${ }^{\text {iD }}{ }^{1}$, Prof. Dr. Cevdet AVCIKURT ${ }^{\text {iD } 2}$
}

\begin{abstract}
$\ddot{O} \mathbf{z}$
Bu çalışmada yerli Y kuşağı turistlerin destinasyon belirleme sürecindeki tutum, sosyal baskı ve algılanan tehditler/faydalar incelenmeye çalışılmıştır. Araştırmanın konusu; yerli Y kuşağı turistlerin destinasyon tercih etme niyetlerinin planlanmış davranış modeli ile incelenmesidir. Çalışma içerisinde; gelecek turizm hareketlerine yön verebilecek olan Y kuşağının davranışa yönelik tutumlarının, sübjektif normlarının, algıladıkları davranışsal kontrollerin ve bu temel etkenleri etkilediği düşünülen birtakım inançların turistik bir destinasyon olan Antalya ilini seçme niyetleri üzerindeki ilişskiler incelenerek satın alma davranışları üzerine çıkarım yapılabilmesi sağlanacaktır. Araştırmada kullanılan birincil veriler, Antalya bölgesinde Y kuşağına mensup bireylere anket uygulanarak elde edilmiştir. Verilerin uygunluğunu yorumlamak için yapılan çeşitli testlerden sonra, değişkenler arası ilişkiyi ortaya koymak amacı ile yapısal eşitlik modellemesi çalışılmıştır. Çalışmada, yerli Y kuşağı turistlerin tutum ve öznel normun destinasyon tercih etme niyetlerinde önemli birer faktör olarak değerlendirilebileceği, algılanan davranış kontrolünün ise anlamsız bir ilişkisinin olduğu ortaya çıkmıştır.
\end{abstract}

Anahtar Kelimeler: Yapısal Eşitlik Modellemesi, Planlanmış Davranış Teorisi, yerli Y kuşağı turist, Antalya

Makale Türü: Araştırma

\begin{abstract}
In this study, the attitude of the domestic $\mathrm{Y}$ generation tourists in Antalya in the process of choosing destination, social pressure and perceived threats / benefits are studied. Subject of the research; The aim of this study is to investigate the intention of the domestic generation $\mathrm{Y}$ to choose a destination with a planned behavior model. In the study; the relationships on the attitude, subjective norm, perceived behavior control, and intention to prefer a touristic destination will be explored by local Y generation tourists. The primary data used in the study was obtained by surveying individuals belonging to local Y generations in the Antalya region. It can be seen that the planned behavior model can be used in the interpretation of destination preference. It has been found out that the local generation of the Y can be considered as important factors in the attitude and subjective norm's intention to prefer destination, while the perceived behavior control has a meaningless relationship in model.
\end{abstract}

Keywords: Structural Equation Modeling, Planned Behavior Theory, Y generation local tourist, Antalya Paper Type: Research

\footnotetext{
* Bu çalışma, Balıkesir Üniversitesi BAP tarafından desteklenmiştir, proje no: BAP-2017/033.

${ }^{1}$ Kırklareli Üniversitesi, Turizm Fakültesi, aysegulkutluk@gmail.com.

${ }^{2}$ Balıkesir Üniversitesi, Turizm Fakültesi, avcikurt@balikesir.edu.tr.
} 


\section{Giriş}

Pazarlamacıların, marka yöneticilerinin, sosyologların, kurumsal iletişimcilerin ve çeşitli konulardan araştırmacıların yeni hedefi olan Y kuşağı, farklı bilim alanlarında incelenmeye başlanmıştır. 1980-2000 yılları arasında doğdukları varsayılan Y kuşağı ile ilgili yapılan ilk yorumlamalarda; Y kuşağının dünya ile ilgisiz, teknolojiye bağıml, ailevi değerleri önemsemeyen, bencil ve saygısız oldukları, iş hayatında tembel oldukları ve olacakları doğrultusundayken zaman içerisinde Y kuşağı ile ilgili raporlanan çoğu olumsuz söylencelerin doğru olmadığı düşünülmeye başlanmıştır.

Türk'e göre (2014); “Türkiye'de özgürlüğüne düşkün, kolay adapte olabilen, çabuk vazgeçen, iyi eğitimli, otoriteye meydan okuyan, teknoloji hayranı olan gençlerden oluşan $\mathrm{Y}$ nesli; sahip oldukları imkânlar sayesinde küreselleşmenin etkilerinin en iyi şekilde hissedildiği, ekonomi ve kültürlerarası etkileşimin arttı̆̆ bir dönemde yaşamaktadırlar". Dolayısıyla çok kültürlülüğe sıcak bakan, uluslararası sınırları dikkate almayan global bir anlayışa sahip (Erciş ve Ünal, 2009: 28) olan bu neslin turizm olgusu içerisindeki davranışları merak edilmektedir. Diğer kuşakların dönemleri düşünüldüğü zaman seyahat etmek veya bir tatil bölgesine gittiğini anlatmak lüks bir davranış olarak görülebilirdi. Fakat günümüzün iyileșen hayat koşulları ve boş zaman faktörünün olumlu yönde artması sayesinde, seyahat etmek lüks bir davranış olmaktan çıkmakta ve bir ihtiyaç haline gelebilmektedir. Böyle bir döneme denk gelen Y kuşağının turizm hareketleri de merak edilen bir konu olmaktadır. Özellikle Y kuşağının turistik ürünleri satın alma veya tercih etme niyetleri sıklıkla araştırılmaktadır. Bu çalışma içerisinde de yerli Y kuşağı turistlerin destinasyon tercih etme niyetlerinin, tutum, öznel norm ve algılanan davranış kontrolü ile ilişkisi irdelenmektedir. Çalışmanın kuramsal alt yapısı Planlanmış Davranış Teorisine (Ajzen, 1991) dayanmaktadır. Bu teoriye göre, davranışın önemli bir öncülü konumundaki davranışsal eğilimler; tutum, öznel norm ve algılanan davranış kontrolü gibi değişkenlerin belirleyiciliğine dayanmaktadır. Davranışsal araştırmalara tutarlılık getirmeye çalışan yaygın, kabul görmüş ve sıklıkla kullanılan bir teori olan planlanmış davranış teorisinde (Schultz, 2014: 4), belirleyici etkenler niyeti etkilemekte niyette davranışın oluşmasını etkileyebilmektedir. Niyetler ne kadar güçlüyse davranış olarak gerçekleşme oranı da orantılı bir şekilde güçleneceği söylenebilmektedir.

\section{Planlanmış Davranış Teorisi}

Davranışlar alanında model ve teori gelişimine yol açan durumlar sosyal psikoloji alanından kaynaklanmaktadır. 1862 gibi erken bir tarihte, psikologlar tutumun davranışları nasıl etkilediğini gösteren teoriler geliştirmeye başlamış, 1918 ve 1925 yıllarında birçok yeni teori ortaya atılmıştır. 19. yüzyıldan itibaren "tutum" terimi ile teorilerin geliştiği varsayılabilir. Çünkü tutumların insanın eylemlerini açıklayabileceği ileri sürülmüştür (Ajzen \& Fishbein, 1980: 13). Tutum-davranış arasındaki ilişkinin güvenilirliği hususunda ihtilaf yaşanmış olmasına rağmen, tutum araştırmalarından vazgeçilmediğini aksine bu ikilinin arasındaki ilişki üzerine çalışmaların daha fazla rağbet görmeye başladığı fark edilmektedir (Kocagöz, 2010: 11). Aslında tutum ve davranış arasındaki tutarsızlık, Ajzen ve Fishbein tarafından 1970'li yıllarda geliştirilen "Mantıksal Eylem Teorisi (Theory of Reasoned Action)" ile giderilmeye çalışılmış, fakat modelin zamanla eksik yönü olan algılanan davranış kontrolü eklenerek "Planlanmış Davranış Teorisi (The Theory of Planned Behavior)" kullanılmaya başlanmıştır (Erten, 2002: 218). Mantıksal Eylem Teorisinde, davranışın kişinin tamamen kendi yetkisinde olduğu vurgulanarak, bireyin davranış üzerindeki kontrolünün (çevresel belirleyiciler ve kaynak durumu) görece olarak önemsiz olduğu varsayılmıştır (Armitage ve Christian, 2003). Planlanmış Davranış Teorisi (PDT), Mantıksal Eylem Teorisi'nin sınır koşullarını, kişinin isteği altında değil, hedefe yönelik davranışa göre genişletmiş̧ir. En sıradan davranışların bile bazen kişinin kontrolü dışındaki faktörlerin etkisine maruz kaldığ 1 varsayılarak (Örneğin: para, zaman, fırsat ve başkalarının iş birliği gibi kaynaklar) istenen davranışların, bir dereceye kadar belirsizliğe maruz kaldığı ve bir kişinin yalnızca niyetine değil, davranışsal denetime müdahale edebilecek faktörlere dayanan bir 
davranış gerçekleştirme şansına sahip olduğunu da ortaya koymaktadır (Netemeyer vd., 1993: 136).

PDT, bireylerin tutumlarının yanı sıra öznel değerlerinin, niyetlerinin ve fark ettikleri davranışsal kontrolün, davranışlarının ortaya çıkmasına katkı sağladığı birçok çalışmada kullanılmıştır. Shaw ve Shiu (2002), etik tüketici davranışını, De Canniere ve arkadaşları (2009) giyim satın alma davranışını, Baker ve White (2010), ergen bireylerin sosyal ağ kullanımını, Middleton ve Smith (2011), taze sebze alım alışkanlığını ve Foster ve Fullagar (2018) ise cinsel taciz bildirim davranışını PDT ile açıklamaya çalışmıştır. Bununla birlikte internetten alışveriş yapma davranışı, hız yapma davranışı, alkollü araba kullanma davranışı, organ ve kan bağışı davranışı, sigarayı bırakma davranışı, gögüs ve prostat kanserine karşı egzersiz yapma davranışı, sağlık çalışanlarının eldiven kullanımı, öğrencilerin suyu ekonomik kullanma davranışları, balık satın alma davranışı, yatırım kararları ve daha çeşitli birçok davranış ve niyetin belirlenebilmesinde de kullanılan bir teoridir. Planlanmış davranış teorisi ile ilgili uygulamalı araştırmaların incelendiği meta-analizler genel olarak değerlendirildiğinde, "niyetlerin davranışa yönelik tutum, sübjektif norm ve algılanan davranışsal kontrol tarafından tahmin edilebileceği ve bu değişkenlerin birlikte değerlendirilerek davranışın açıklanabileceği” sonuçlarına ulaşılmaktadır (Ajzen, 2008). Turizm alanında yapılan çalışmalarda; Schubert ve diğerleri (2008) çevreci restoranda yemek yeme niyetini açıklamak üzere PDT'nin üç belirleyici değişkeni ile birlikte demografik değişkenlerin de etkisini dikkate alarak bir model oluşturmuştur. Sparks ve Pan (2009), Çin'den yurtdışına giden turistlerin değerlerini belirleyebilmek için hem destinasyon nitelikleri hem de uluslararası seyahatlere yönelik tutumları araştırmış; seyahat etme niyetlerini tahmin etme açısından sosyal normların ve algılanan davranış kontrollerinin büyük ölçüde etkili oldukları bulunmuştur. Aynı çalışmada bir destinasyon hakkında bilgi aramak için bilgi kaynaklarının kullanımı da araştırılmıştır. Elde edilen kanıtlar, televizyon programlarının Çin halkının destinasyon tercihleri hakkında bilgi edinmek için kullandığı önemli bir bilgi kaynağ olduğuna işaret etmektedir. Lai ve arkadaşları (2010) bir hizmet şikayetini takiben turistlerin hizmet iyileştirme algısını ve bu unsurların tema parkını tekrar ziyaret etme niyetiyle nasıl ilişkili olduklarını PDT modeli ile incelemişler, etkileşimli adalet, tutum ve sübjektif normların temalı parkları tekrar ziyaret etmede etkili olduklarını belirtmişlerdir. Han, Hsu ve Sheu (2010); planlı davranış teorisinin yeşil otel seçimine uygulanması isimli çalışmasında teori ile tutarlı olarak yapısal bir denklem analizi sonucunda tutum, öznel norm ve algılanan davranış kontrolü yeşil bir otelde kalma niyetini olumlu etkilemiştir. Reddy ve arkadaşları (2010) öğrencilerin medikal turizme katılma niyetlerini araştırırken, tıbbi bir tedaviyi almak için gelişmekte olan bir ülkeye seyahat etmede bilgi edinme için pozitif niyetlerinin olmaması dikkat çekmektedir. Martin ve arkadaşlarının, 2011 yılında yapmış oldukları çalışmada PDT modeli yardımıyla medikal turizm niyetlerini ölçmek için "MEDTOUR" ölçeğini geliştirmişlerdir. Aynı yazarlar 2015 yılında öğrencilerin tıbbi turizmle uğraşma niyetini öngören bir önceki çalışmanın uzatılması ve çoğaltılması yoluyla planlı davranış teorisini sağlık bakım pazarlamacılarına MEDTOUR ölçeği kullanarak tanıtmaktadır. Yamada ve Fu (2012), Müzeleri ziyaret etmede belirgin inançların gücü ve önemini belirleme amacıyla, davranışsal, normatif ve algılanan davranışsal kontrol inançlarını bir araya getirmek için Indiana Eyalet Müzesindeki ziyaretçilerle görüşmeler ve anketler yapılmış; aile üyelerinin normlarının ziyaretlerde etkili olduğu görülmüştür. PDT modeli ile Spa ziyaretine yönelik davranışın ölçülmesinde "geçmiş tecrübeleri" ve "sağlıklı yaşam" değişkenlerinin etkisini ölçmeye çalışan Kim ve arkadaşları (2010) geçmiş tecrübelerin niyetle pozitif ve olumlu, sağlıklı yaşam değişkeninin ise negatif yönlü bir ilişki oluşturduğunu belirtmiştir. Benzer bir çalışma olarak; ABD'de Wellness turizm endüstrisinin büyümesine neden olan faktörler arasındaki doğrudan ilişkileri inceleyen Hudson ve arkadaşları (2017) "yaşam stresi" ve "sağlıklı yaşama katılım" değişkenlerinin niyet üzerinde olumlu etkilerini kaydetmiştir. 


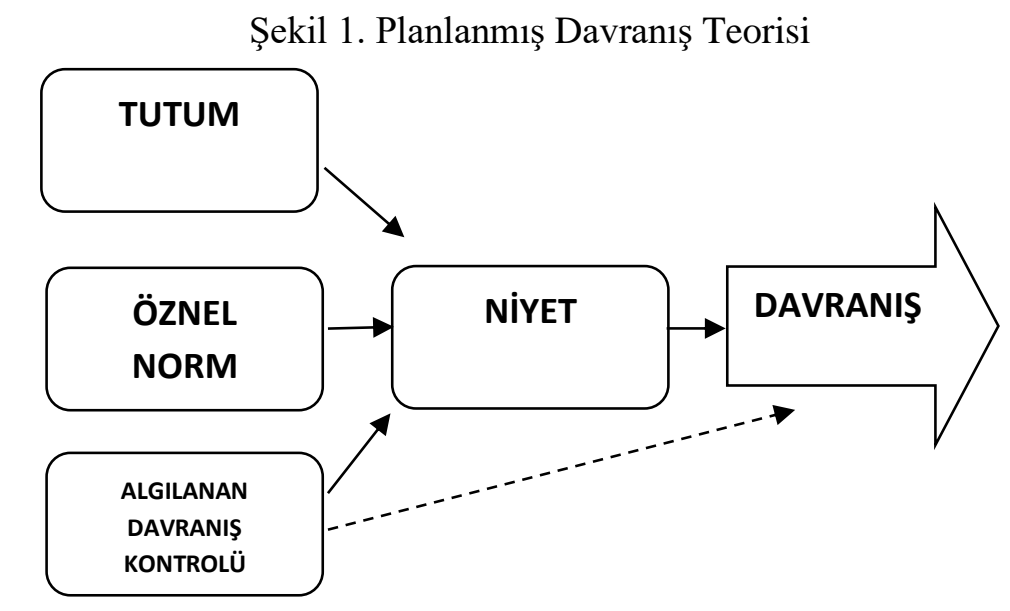

Kaynak: Ajzen, (1991) ve Erten, S (2002).

Tutum: Tutum, "kişiye ya da çevresindeki bir nesne, toplumsal konu, olaylara karşı deneyim, bilgi, duygu ve güdülerine (motivasyon) dayanarak organize ettiği zihinsel, duygusal ve davranısssal tepkilerin ön eğilimidir" (İnceoğlu, 2010: 13). PDT' de ise tutum; "söz konusu bir davranış gerçekleştirildiğinde birtakım çıtıtılara ya da sonuçlara ulaşılacağı yönünde bireylerin sahip oldukları inançlar ve davranışla ilgili inançların içerisinde geçen çıktıların kişisel değerlendirilmesiyle açıklanır" (Ajzen, 1991). Tutum, turistik motivasyon ve davranış için bir model geliştirilmesinde tartışmanın en kritik konularından biridir. Tutumlar ile ilgili çalışma konusu olan kilit paydaşlardan birisi turisttir (Vargas-Sánchez vd., 2015:3).

Subjektif Norm: Subjektif normlar, kişinin belirli bir davranış göstermesi gerekip gerekmediğine dair diğer kişilerin görüşlerine yönelik algılamalarına atıfta bulunurken, algılanan davranışsal kontrol, bir bireyin bir davranışı gerçekleştirmek için gerekli olan kaynakların veya fırsatların varlığı veya yokluğuna ilişkin algılamalarına atıfta bulunmaktadır (Luarn ve Lin, 2005: 876). Dolayısıyla kişinin, davranışları hakkında ne düşünüleceğiyle ilgili inançları ve kişinin bu düşüncelere ne ölçüde tepki vereceği (uyması veya reddetmesi), niyetini etkilemektedir (Kağıtçıbaşı ve Cemalcılar, 2015: 141).

Algılanan Davranış Kontrolü: Algılanan davranışsal kontrol, "herhangi bir davranışı gerçekleştirmenin kendi kontrolünde olup olmadı̆̆ yönünde bireylerin yetenekleri ve imkânlarıyla ilgili algılamalarını ifade etmektedir ve davranışın performansını kolaylaştıran veya baskı altına alan faktörlere bağlı olarak şekillenir" (Kocagöz ve Dursun, 2010: 141). Planlanmış Davranış Teorisine göre niyetlerin üçüncü öncüsü, algılanan davranışsal kontrol derecesi, davranışın gerçekleştirilmesinde kolaylık veya zorluk olarak algılanmaktadır (Kolvereid, 1997: 49; Tkachev ve Kolvereid, 1999: 272). Bir kişinin kullanabileceği kaynaklar ve firsatlar bir dereceye kadar davranışsal başarı olasılığını belirlemektedir (Ajzen, 1991: 183).

Niyet: Ajzen (1991)'e göre niyet, "bireyin bir davranışı gerçekleştirmek için gösterdiği isteklilik ve harcadiğ çabanın yoğunluğudur". Algılanan Davranış kontrolü, daha önceki konuda bahsedildiği üzere; bir bireyin hedeflenen davranış üzerinde önemli bir denetime sahip olmadığ durumlarda ortaya çıkan (Luarn ve Lin, 2005: 876) ve planlı davranış teorisinde önemli bir rol oynayan niyetin yordayıcısıdır. Nitekim mantıklı eylem teorisine algılanan davranışsal kontrolün eklenmesi ile ortaya çıkmış olan PDT (Ajzen, 1991: 183) insan davranışlarına daha açıklayıcı bir nitelik kazandırmıştır (Usluel ve Mazman, 2010: 63).

Davranış: Davranış organizmanın, içten ve dıştan kaynaklanan etkilere veya uyarıcılara karşı gösterdiği bilinçli tepkileri ifade etmektedir. Bununla birlikte davranışı hareketten ayıran en temel faktör de bilinçli tepkiler olması özelliğidir (Tutar, 2015: 53). Bir davranış1 yapmaya ilişkin tutum, öznel norm ve davranışlar üzerinde algılanan kontrol ne derece olumluysa, o davranış1 yapma niyeti de o denli olumlu olacaktır (Middleton ve Smith, 2011: 250). Diğer bir ifadeyle bir 
kişi herhangi bir engel algılamadığı bir zaman diliminde, tatil yapma/tatile çıkma davranışının iyi ve yararlı bir davranış olduğunu düşünüp, sosyal çevresinden bu konuda destek alabiliyorsa ve yeterli miktarda parası/zamanı da var ise bu niyetin davranışa dönüşmesi çok büyük olasılıkla mümkün olacaktır.

\section{Araştırmanın Yöntemi}

Bu çalışmada, Ajzen $(1985,1991)$ 'in geliştirdiği planlanmış davranış teorisinin modeli kullanılarak Antalya'daki yerli Y kuşağı turistlerin destinasyon tercihleri için olan niyetleri incelenmeye çalışılmıştır. Y kuşağı; Milenyum kuşağı, dijital kuşak ve sonraki kuşak gibi farklı isimlendirmelere sahip, ortalama 1982-2000'li yılları arasında doğmuş olan grubu ifade etmeye yarayan bir kavramdır (Bozkurt, 2018). Hammill (2005), Y kuşağı insanlarının, gerçekçi, eğlenceyi seven, sosyal ve huzur içinde yaşamayı bilen insanlar olduğunu belirtmektedir. Pendergast, (2010: 11)'in Y kuşağı değerlendirmesinde; seyahat deneyimleri konusunda aç ve cesur olmalarından ve Y kuşağına göre seyahat etmenin, bir yaşam biçimi olduğu ve seyahat sırasında oluşabilecek risklerin de aşılamayacak engeller olmadığını düşündükleri belirtilmektedir.

Araştırmada veri toplama aracı olarak kullanılan anket üç bölümden oluşmaktadır. Anketin birinci kısmında anketin hangi amaçla hazırlandığı ile ilgili açıklama, katılımcıların demografik özelliklerini saptamaya ilişkin sorular ve Antalya iline seyahat etmeyi seçmede etkili olacak ifadeler bulunmaktadır. Anketin ikinci bölümünde ise PDT' nin değişkenlerine (tutum, öznel norm, algılanan davranışı kontrolü ve niyet) ilişkin sorular bulunmaktadır. Cevaplayıcılardan tutum maddeleri 5'li önem derecelendirmesiyle (1. Hiç önemli değil, 5. Çok önemli) değerlendirmeleri istenmiş, öznel norm, algılanan davranış kontrolü ve niyet ölçeklerinin maddeleri ise 5'li likert tipi (1. Kesinlikle Katılmıorum, 5. Kesinlikle Katılıyorum) ile değerlendirilmiştir. Ölçekler için yararlanılan kaynaklar ise şöyledir;

- Tutum: Lam and Hsu, 2006, Lee et al, 2007, Sparks, 2009, Kocagöz, 2010.

- Öznel Norm: Lam and Hsu, 2006, Kocagöz, 2010, Ryu and Han, 2010. Perugini ve Bagozzi, 2001.

- Algılanan Davranış Kontrolü: Lam and Hsu, 2006, Sparks, 2009, Kocagöz, 2010.

- Niyet: Kocagöz, 2010, Ryu and Han, 2010.

Çalışmada kullanılan veriler Antalya ilinde tatil yapmakta olan yerli Y kuşağı (19822000) turistlerden yüzyüze mülakat şeklinde toplanmıştır. Antalya, Türkiye'nin ve dünyanın en önemli turizm bölgelerinden biridir. İlin kara, deniz ve hava yolları ile iç ve dış pazarlarla bağlantılı olması her yönü ile kapasiteyi artırmaktadır (TÜİK, 2013). Türkiye'nin en fazla turist çeken illerinden biri olması ve sahip olduğu cezbedici turistik tesislerin yoğunluğu nedeniyle bu araştırmanın evreni Antalya olarak belirlenmiştir. Evrenin tam olarak kaç kişiden oluştuğunun ya da özelliklerinin tam olarak bilinmediği gruplar için örneklem çerçevesi oluşturmak zor olduğu için olasılığa dayalı olmayan (yargısal) örnekleme seçim teknikleri kullanılmaktadır (Lin, 1976: 15). Olasılığa dayalı olmayan örnekleme seçiminde örneklem tesadüfen seçilmemekte, "seçilecek örneklerde belirli özelliklerin varlığı" aranmaktadır (De Vaus, 1990: 60). Bu sebeple, örneklemin belirlenmesinde Olasılıklı Olmayan Örnekleme türlerinden yaş değişkenine göre sınırlandırma olduğu için Kotalı Örnekleme türleri birlikte kullanılmıştır. Kota örnekleme, evreni değişik kategorilere bölmeyi ve her bir kategoride bulunan eleman sayısı ile orantılı, onları temsil eden gruplarla örneklem oluşturulur (Özen ve Gül, 2007: 414). 2017 yılı itibari ile Y kuşağı yaş aralığını 18-35 yaş arasındaki bireyleri kapsamaktadır. Kotalı örnekleme seçimine uygun olarak her yaş aralığındaki bireylere (18 ile 35 yaş arasında 18 birim mevcuttur) 40'ar adet anket uygulanması öngörülmüştür. Toplamda 720 anket, Antalya il merkezi ve ilçelerinde 2017 Haziran- 2017 Ekim ayları arasında uygulanmış, bunların 56 tanesi farklı kuşağa ait birey olma, eksik ve tutarsız bilgiler vb. sebeplerden dolayı çalışma dışı bırakılmıştır. Dolayısıyla araştırmada 664 yerli Y kuşağı turistlerine anket uygulamasından elde edilen veriler ile analizler gerçekleştirilmiştir. İstatistiksel analizler IBM SPSS Statistics 22 paket programında, doğrulayıcı 
faktör analizi ve yapısal eşitlik model analizi IBM AMOS 22 programında yapılmıştır. Ölçeklere doğrulayıcı faktör analizi yapılmış ve yapısal eşitlik modellemesi ile değerlendirme yapılmıştır. Yapısal eşitlik modelleme "ölçüm hatalarını dikkate alan ve her biri birden fazla gözlenebilir değişkenle ölçülen çoklu bağımsız ve bağımlı örtük değişkenler arası iliş̧kileri ortaya koyan ve test eden güçlü bir istatistiksel tekniktir" (Taşkın ve Akat, 2010: 2). Araştırma modeli ise aşağıdaki gibidir.

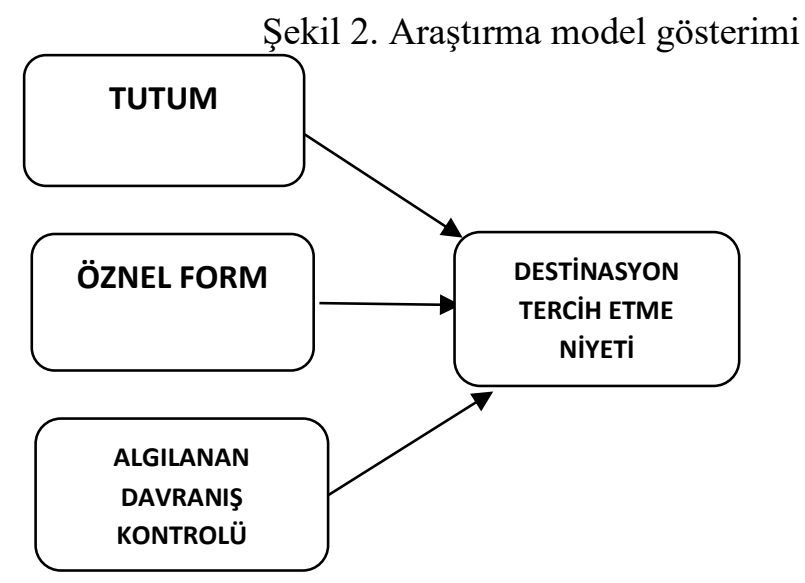

Araştırmada, kuramsal çerçeve doğrultusundan oluşturulan üç adet araştırma hipotezi bulunmaktadır.

- H1 Tutumların destinasyon tercih etme niyeti üzerinde pozitif yönlü etkisi vardır.

- H2 Öznel Normların destinasyon tercih etme niyeti üzerinde pozitif yönlü etkisi vardır.

- H3 Algılanan Davranış Kontrolünün destinasyon tercih etme niyeti üzerinde pozitif yönlü etkisi vardır.

\section{Bulgular}

\subsection{Demografik Bilgiler İle İlgili Analizler}

Katılımcıların \%45,6'sı erkek (n=303), iken \%54,4'ü kadındır ( $\mathrm{n}=361)$. 18-26 yaş aralığındaki yerli Y kuşağı katılımcıları \%47,1, $(\mathrm{n}=313), 27-35$ yaş aralığındaki yerli $\mathrm{Y}$ kuşağ $\% 52,9(\mathrm{n}=351)$ oranındadır. Katılımcıların eğitim durumlarına göre dağılımları şu şekildedir; $\% 0,2$ ortaokul $(\mathrm{n}=1), \% 2,1$ lise $(\mathrm{n}=14), \% 3,6$ ön lisans $(\mathrm{n}=24), \% 86,6$ lisans $(\mathrm{n}=575), \% 5$ yüksek lisans $(\mathrm{n}=33), \% 2,5$ doktora $(\mathrm{n}=17)$ mezunudur. Katılımcıların \%20,82'si evli $(\mathrm{n}=138)$ iken, $\% 79,2$ 'si bekar (n=526) dır. Tablo 1 de görüleceği gibi katılımcıların mesleklerine göre dağılımları ise şu şekildedir; \%50,3'ü kamu sektörü çalışanı $(n=334), \% 27,7$ 'si özel sektör çalışanı ( $\mathrm{n}=184), \% 99^{\prime} \mathrm{u}$ işletme sahibi/girişimci $(\mathrm{n}=60), \% 8,4^{\prime}$ ü öğrenci $(\mathrm{n}=56), \% 4,5$ 'i ise diğer $(\mathrm{n}=30)$. Ev hanımı olarak hiç kimse araştırmaya katılmamıştır. Son olarak katılımcıların aylık gelir seviyelerine göre dağılımları ise şu şekildedir; \%11'i 1000 TL ve altı (n=73), \%28'i 10013000 TL arası ( $n=186), \% 41,4$ 'ü 3001-5000 TL arası ( $n=275), \% 19,6$ 's 5001 TL ve üzeri (n=130) gelir seviyesindedir. Bu bilgiler doğrultusunda Tablo.1 de katılımcıların demografik verileri gözlemlenebilir. 
Tablo 1. Yerli Y kuşağı turistlerin demografik bilgileri

\begin{tabular}{|c|c|c|c|c|c|c|c|}
\hline \multicolumn{2}{|c|}{ Demografik Özelikler } & \multirow{2}{*}{$\begin{array}{c}\text { Frekans } \\
\text { (n) } \\
303\end{array}$} & \multirow{2}{*}{$\begin{array}{c}\text { Yüzde } \\
\text { (\%) } \\
45,6 \%\end{array}$} & \multirow{2}{*}{\multicolumn{2}{|c|}{$\begin{array}{l}\text { Demografik Özelikler } \\
\text { Kamu sektörü çalışanı }\end{array}$}} & \multirow{2}{*}{$\begin{array}{c}\text { Frekans } \\
\text { (n) } \\
334\end{array}$} & \multirow{2}{*}{$\begin{array}{c}\text { Yüzde } \\
\text { (\%) } \\
50,3 \%\end{array}$} \\
\hline Cinsiyet & Erkek & & & & & & \\
\hline & Kadın & 361 & $54,4 \%$ & & Özel sektör çalışanı & 184 & $27,7 \%$ \\
\hline & Toplam & 664 & $100,0 \%$ & & İşletme sahibi/girişimci & 60 & $9,0 \%$ \\
\hline \multirow[t]{3}{*}{ Yaş } & $18-26$ & 313 & $47,1 \%$ & \multirow{3}{*}{ Meslek } & Öğrenci & 56 & $8,4 \%$ \\
\hline & $27-35$ & 351 & $52,9 \%$ & & Ev hanımı & 0 & $0,0 \%$ \\
\hline & Toplam & 664 & $100,0 \%$ & & Diğer & 30 & $4,5 \%$ \\
\hline \multirow[t]{7}{*}{ Eğitim } & Ortaokul & 1 & $0,2 \%$ & \multirow{10}{*}{ Gelir } & Toplam & 664 & $100,0 \%$ \\
\hline & Lise & 14 & $2,1 \%$ & & 1000 tl ve alt 1 & 73 & $11,0 \%$ \\
\hline & Ön lisans & 24 & $3,6 \%$ & & $1001-3000 \mathrm{TL}$ & 186 & $28,0 \%$ \\
\hline & Lisans & 575 & $86,6 \%$ & & 3001-5000 TL & 275 & $41,4 \%$ \\
\hline & Yüksek lisans & 33 & $5,0 \%$ & & 5001 TL ve üstü & 130 & $19,6 \%$ \\
\hline & Doktora & 17 & $2,6 \%$ & & Toplam & 664 & $100,0 \%$ \\
\hline & Toplam & 664 & $100,0 \%$ & & & & \\
\hline \multirow{3}{*}{$\begin{array}{l}\text { Medeni } \\
\text { Durum }\end{array}$} & Evli & 138 & $20,8 \%$ & & & & \\
\hline & Bekar & 526 & $79,2 \%$ & & & & \\
\hline & Toplam & 664 & $100,0 \%$ & & & & \\
\hline
\end{tabular}

\subsection{Planlanmış Davranış Modeli İle İlgili Analizler}

Çalışmada örnek alınan Ajzen' nin "Planlanmış Davranış Teorisi” modelinde davranışın tetiklenmesinde etkili olduğu düşünülen bağımsız değişkenler; tutum, öznel norm, algılanan davranışsal kontrol ve davranışsal niyettir. Bu değişkenlere ait ölçekler ile, katılımcıların ölçeklerdeki ifadelere verdikleri yanıtların ortalamaları ve standart sapmalar gibi aşağıda betimleyici istatistikler sunulmaktadır.

Tablo 2. Bağımsız değişkenlere yönelik betimleyici istatistikler

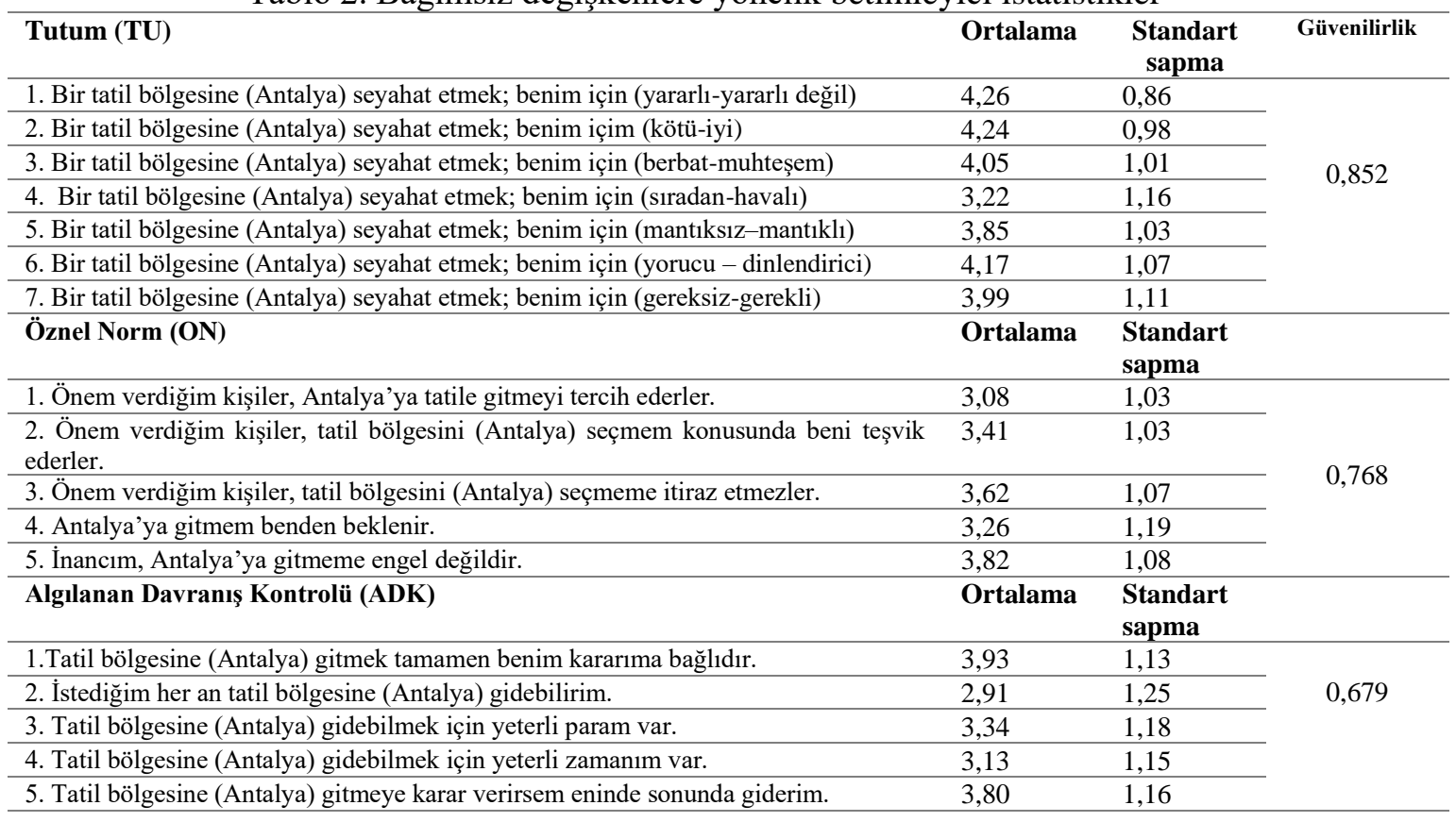




\begin{tabular}{|c|c|c|c|}
\hline Destinasyon Tercih Etme Niyeti (DTEN) & Ortalama & $\begin{array}{l}\text { Standart } \\
\text { sapma }\end{array}$ & \\
\hline 1. Antalya hakkında çevremdekilere olumlu şeyler söylerim & 3,65 & 0,95 & \multirow{5}{*}{0,862} \\
\hline 2. Çevremdeki kişilere, aileme ve arkadaşlarıma Antalya'yı öneririm. & 3,65 & 0,91 & \\
\hline $\begin{array}{l}\text { 3. Antalya’yı başka tüketicilerinde tercih etmelerinin doğru bir karar olacağını } \\
\text { söylerim. }\end{array}$ & 3,55 & 0,97 & \\
\hline $\begin{array}{l}\text { 4. İleride tatil destinasyonu için tekrar karar vermem gerektiğinde yine Antalya’yı } \\
\text { tercih ederim. }\end{array}$ & 3,24 & 1,05 & \\
\hline 5. Antalya ile ilgili pozitif düşüncelerim var. & 3,79 & 0,92 & \\
\hline
\end{tabular}

Tutumu ölçen ifadeler arasında ortalama olarak en yüksek skorları 1, 2 ve 6 nolu ifadeler almıştır. Katılımcılar bir tatil destinasyonunda bulunmanın kendileri için yararlı, iyi ve dinlendirici olduğunu belirtmişlerdir. Sübjektif norm grubunda en yüksek skorları 5 ve 3 nolu ifadeler almıştır. Buna göre; katılımcıların önem verdikleri kişiler onların destinasyon tercihlerinde etkilidir ve katılımcıların inançları tatil destinasyonuna gitmesine engel değildir denilebilir. En düşük skor ise; katılımcıların önem verdiği kişilerin, Antalya destinasyonuna tatile gitme tercihi konusunda kararsız kaldıklarını göstermektedir. Algılanan davranış kontrolü grubunda en yüksek skor 1 ve 5 nolu ifadelerdir. Katılımcılar bir tatil bölgesine gitmek isterlerse bunun tamamen kendi kararları ile olduğunu ve tatile gitme kararı verdikten sonra mutlaka gideceklerini ifade etmişlerdir. "İstediğim her an tatil bölgesine giderim" önermesi ise en düşük skorlu önermedir. Destinasyon tercih etme niyeti grubunun en yüksek skorlu ifadeleri, 5, 1 ve 2'dir. Katılımcıların çoğunluğunun Antalya ile ilgili pozitif düşünceleri vardır.

Yapısal modelde yer alan ölçekler Doğrulayıcı Faktör Analizine (DFA) tabi tutulmuş ve yeterli uyum iyiliği istatistiklerine sahip olduğu sonucuna ulaşılmıştır. Uyum iyiliği indeksleri genellikle model tarafından açıklanan varyans ve kovaryans miktarının bir ölçümüdür. Ölçeklerle ilgili söz konusu değerler Tablo 3'de gösterilmektedir.

Tablo 3. Ölçeklerin doğrulayıcı faktör analizi model uyum iyiliği indeksleri

\begin{tabular}{|c|c|c|c|c|c|c|c|}
\hline & $\begin{array}{l}\text { CMIN/D } \\
\text { F }\end{array}$ & AGFI & GFI & CFI & RMSEA & AVE & CR \\
\hline \multirow{4}{*}{$\begin{array}{l}\text { Kabul } \\
\text { edilebilir } \\
\text { uyum* } \\
\text { Mükemmel } \\
\text { uyum** }\end{array}$} & \multirow{2}{*}{$\begin{array}{l}2 \leq \mathrm{CMIN} / \\
\mathrm{DF} \leq 3\end{array}$} & $0.85 \leq \mathrm{AGFI} \leq$ & $0.90 \leq \mathrm{GFI} \leq$ & \multirow{2}{*}{$\begin{array}{l}0.90 \leq \mathrm{CF} \\
\mathrm{I} \leq 0.95\end{array}$} & \multirow{2}{*}{$\begin{array}{l}0.05 \leq \mathrm{RMSE} \\
\mathrm{A} \leq 0.08\end{array}$} & & \\
\hline & & 0.90 & 0.95 & & & & \\
\hline & \multirow{2}{*}{$\begin{array}{l}0 \leq \chi^{2} / \mathrm{sd} \leq \\
2\end{array}$} & $0.90 \leq \mathrm{AGFI} \leq$ & $0.95 \leq \mathrm{GFI} \leq$ & $0.95 \leq \mathrm{CF}$ & $0.00 \leq \mathrm{RMSE}$ & & \\
\hline & & 1.00 & 1.00 & $\mathrm{I} \leq 1.00$ & $\mathrm{~A} \leq 0.05$ & & \\
\hline ON & $0.341 * *$ & $0.997 * *$ & $1.000 * *$ & $1.000 * *$ & $0.000 *$ & ,47 & ,74 \\
\hline TU & $2.202 *$ & $0.989 * *$ & $0.973 * *$ & $0.993^{* *}$ & $\mathrm{0.043}^{* *}$ &, 54 &, 84 \\
\hline ADK & $0.17 * *$ & $1.000 * *$ & $1.000 * *$ & $1.000 * *$ & $0.000 * *$ &, 52 &, 74 \\
\hline DTEN & $0.958 * *$ & $0.991 * *$ & $0.998 * *$ & $1.000 * *$ & $0.000 * *$ &, 56 &, 89 \\
\hline
\end{tabular}

"Uyum iyiliği indekslerinin değeri l'e ne kadar yaklaşırsa modelin veriye o kadar uyumlu olduğu söylenebilir. Uyum iyiliği indeksleri için 0,90-0,95 kabul edilebilir ve 0,95 üzerinde olması ise yüksek bir uyumu göstermektedir" (Byrne, 1998). Genellikle, "GFI ve AGFI değerlerinin 0.90'dan yüksek olması, RMSEA değerinin ise 0.05 dan düşük çıkması, model veri uyumunu göstermektedir" (Marsh ve Hocevar, 1988). DFA yaparken veya DFA yapılmış bir ölçeği incelerken bu indeksler araştırıcıya ölçeği değerlendirme firsatı verir (Çapık, 2014: 199). Yukarıdaki tabloda yer alan bilgiler 1şığında; ölçeğin yapısal geçerliliğe ve güvenirliliğe sahip, bilimsel amaçlı ölçme işlevini yerine getirebilecek bir ölçme aracı olduğu söylenebilmektedir. Ölçeklerin son olarak standardize edilmiş faktör yüklerine ve $t$ değerlerine bakılmıştır. Tablo 4.de bu bilgiler yer almaktadır. 
Tablo 4. Yakınsak geçerlilik sonuçları

\begin{tabular}{|c|c|c|c|c|c|}
\hline & Standardize & & & Standardize & \\
\hline Faktörler & $\begin{array}{l}\text { Edilmiş Faktör } \\
\text { Yükleri }\end{array}$ & $\begin{array}{l}\text { T- } \\
\text { değerleri }\end{array}$ & Faktörler & $\begin{array}{l}\text { Edilmiş Faktör } \\
\text { Yükleri }\end{array}$ & $\begin{array}{l}\text { T- } \\
\text { değerleri }\end{array}$ \\
\hline Tutum & & & $\begin{array}{l}\text { Destinasyon } \\
\text { Tercih Etme } \\
\text { Niyeti }\end{array}$ & & \\
\hline TU2 & 0,705 & $\begin{array}{l}\text { 1'e } \\
\text { sabitlenir }\end{array}$ & DTEN1 & 0,789 & $\begin{array}{l}\text { 1'e } \\
\text { sabitlenir. }\end{array}$ \\
\hline TU3 & 0.729 & 20,261 & DTEN2 & 0,860 & 20,205 \\
\hline TU5 & 0,792 & 17,190 & DTEN3 & 0,857 & 20,927 \\
\hline TU6 & 0,669 & 16,174 & DTEN4 & 0,598 & 14,771 \\
\hline TU7 & 0.803 & 17,323 & DTEN5 & 0,620 & 15,355 \\
\hline $\begin{array}{l}\text { Öznel Norm } \\
\text { (Sosyal } \\
\text { Baskı) }\end{array}$ & & & $\begin{array}{l}\text { Algılanan } \\
\text { Davranış } \\
\text { Kontrolü }\end{array}$ & & \\
\hline ON1 & 0,831 & $\begin{array}{l}\text { 1'e } \\
\text { sabitlenir. }\end{array}$ & ADK2 & 0,698 & $\begin{array}{l}\text { 1'e } \\
\text { sabitlenir. }\end{array}$ \\
\hline ON2 & 0,665 & 11,322 & ADK3 & 0,779 & 10,765 \\
\hline ON4 & 0,562 & 10,662 & ADK4 & 0,663 & 9,864 \\
\hline ON5 & 0,567 & 10,815 & ADK5 & 0,575 & 8,819 \\
\hline
\end{tabular}

\subsection{Yapısal Modelin Test Edilmesi- Yol Analizi}

Sosyal bilimler alanında özellikle doğrudan gözlemlenebilmesi ve ölçülebilmesi mümkün olmayan yarg1, değerlendirme, motivasyon, davranış vb. yapı ve kavramların analizlerinde sıklıkla ölçüm hataları çıkabilmektedir (Wang, 2012: 1). Klasik analiz yöntemleri ile aşılamayan istatistik sorunlar nedeniyle ve ölçülmek istenen yapılar arasındaki ilişkiler tek seferde bir bütün olarak ortaya çıkarması sayesinde son yıllarda YEM analizi daha sık tercih edilmeye başlanmıştır. Dolayısıyla araştırma kapsamında yapılar/ölçekler arası ilişkilerin irdelenmesine dayalı hipotezlerin sınanması amacıyla, ölçeklerin yapısal geçerlilik ve güvenirlilik sağlayan yapıları ile yapısal eşitlik modeli çözümlenmesinden yol analizi yapılmıştır. Yol analizi, "yapısal eşitlik modelinde değişkenler arasındaki istatistiksel iliş̧kileri ayrıştırmak için kullanılmaktadır" (Güzeller, 2006: 406). "Yol analizi içinde yer alan yol katsayılarl, bir değişkeni yordayan diğer değişkenler sabit tutulduktan sonra hesaplanan regresyon katsayılarl olarak yorumlanabilirler" (Çepni, 2010).

Yapısal model için elde edilen uyum indeks değerlerinin uygun olduğu görülmektedir: $\mathrm{x} 2=217,731(\mathrm{df}=124, \mathrm{p}<0,001), \mathrm{x} 2 / \mathrm{df}=1,756 \mathrm{GFI}=0,964$, AGFI $=0,951, \mathrm{NFI}=0,952, \mathrm{CFI}=$ 0,978 , RMSEA $=0,034$. Modelde yer alan değişkenler arası ilişkilerin istatistiksel anlamlılıkları Tablo 5'de gösterilmektedir.

Tablo 5. Planlanmış Davranış Modelinin Yapısal Eşitlik Modellemesi ile yol analizi

\begin{tabular}{|c|c|c|c|c|c|}
\hline & lişki & & $\begin{array}{l}\text { Standart } \\
\text { Regresyon } \\
\text { Katsayıları }\end{array}$ & *C.R. & $\mathbf{P}$ \\
\hline $\begin{array}{l}\text { Destinasyon Tercih Etme } \\
\text { Niyeti }\end{array}$ & $\begin{array}{ll}<- \\
--\end{array}$ & Subjektif Norm & ,397 & 7,846 & $* * *$ \\
\hline $\begin{array}{l}\text { Destinasyon Tercih Etme } \\
\text { Niyeti }\end{array}$ & $\begin{array}{l}<- \\
--\end{array}$ & $\begin{array}{l}\text { Algılanan Davranış } \\
\text { Kontrolü }\end{array}$ & ,076 & 1,180 & ,238 \\
\hline $\begin{array}{l}\text { Destinasyon Tercih Etme } \\
\text { Niyeti }\end{array}$ & $\begin{array}{l}<- \\
--\end{array}$ & Davranışa Yönelik Tutum & ,208 & 4,680 & $* * *$ \\
\hline
\end{tabular}

Model içerisinde öznel normun, destinasyon tercih etme niyeti üzerinde istatistiksel olarak anlamlı ve pozitif bir etkisinin olduğu görülmektedir. $(\beta=0.397, p=0.000)$. Katsayısının pozitif olması değerlendirme ölçeğinde meydana gelen bir artışı destinasyon tercih etme niyeti üzerinde katsayı ile orantılı bir artışa sebep olduğu veya aksi bir durumda öznel norm ölçeğinde 
meydana gelen bir azalışın da davranışsal niyet ölçeğinde katsayı ile orantılı bir azalışa neden olacağı şeklinde yorumlanabilir. Aynı şekilde tutum ölçeğinin destinasyon tercih etme niyeti üzerinde \%95 güven düzeyinde istatistiksel olarak anlamlı ve pozitif bir etkisinin olduğu görülmektedir. $(\beta=0.208, \mathrm{p}=0.000)$. Katsayısının pozitif olması değerlendirme ölçeğinde meydana gelen bir artışın destinasyon tercih etme niyeti üzerinde katsayı ile orantılı bir artışa sebep olduğu veya aksi bir durumda tutum ölçeğinde meydana gelen bir azalışın da destinasyon tercih etme niyet ölçeğinde katsayı ile orantılı bir azalışa neden olacağı şeklinde yorumlanabilmektedir. Algılanan davranış kontrolü ölçeğinden destinasyon tercih etme niyetine çizilen yol ise $p<, 05$ düzeyinde anlamsız, dolayısıyla ilişkisiz çıkmıştır. Bu durumda H1 ve H2, hipotezleri kabul edilmiş, H3 hipotezi reddedilmiştir.

\section{Tartışma, Sonuç ve Öneriler}

$\mathrm{Bu}$ çalışmada elde edilen bulgulara göre; planlanmış davranış teorisi Antalya destinasyonunu tercih etme niyetinin belirlenmesinde kullanılabilecek uygun bir model olmadığ 1 gözlenmiştir. Algılanan davranış kontrolünün değişken olarak yer almadığı Mantıksal Eylem Teorisinin kullanılmasının daha uygun olacağı düşünülmektedir.

Çalışmadan elde edilen veriler ışığında; Antalya destinasyonunu tercih etme niyetine en güçlü etkiyi öznel normların sağladığı ortaya çıkmıştır. Baker ve White (2010), Han ve Kim (2010), Mulan ve Wong (2010), Jalilvand ve Samiei (2012), Alonso ve arkadaşları ve Wang ve arkadaşlarının (2018) turizm alanındaki çeşitli çalışmalarında öznel normun niyeti etkileyebileceğini ifade etmişlerdir. Öznel normların (çevresel etkilerin, arkadaş, akraba, dost veya tanıdık tavsiyelerin ve yine yakın çevrenin yapmasını onayladığı veya istediği şeyleri yapmak) Y kuşağı bireylerinin destinasyon belirleme niyetlerini etkileyen en güçlü değişken olduğu görülmektedir. Dolayısıyla,Y kuşağı yerli turistlerin seyahate çıkmadan önce otel kullanıcı yorum portallarına ve sosyal mecralarda paylaşılan yorumlara bakması beklenebilir. Çünkü Y kuşağı üyeleri için, "dünyanın herhangi bir yerinden Skype, MySpace, Facebook gibi sosyal medya platformlarl aracılĭğyla arkadaş edinmek, bloglardan yemek tarifi ögrenmek, müzikleri cd çalar yerine ipoddan dinlemek, ödev araştırması yaparken kütüphaneye gitmek yerine Google'ı kullanmak, günlük yazmak yerine blog yazmak olağanüstü davranışlar değildir" (Etlican, 2012: 7-8). Dolayısıyla, bloglarda ve sosyal medyanın ortak kullanım alanlarında yerli Y kuşağ turistlerinin olumlu veya olumsuz tavsiyelerinin stratejik bir şekilde yönetilebilmesi turizm işletmeleri açısından önem taşıyabilir. Genel olarak Y kuşağı bireylerinin de üzerinde arkadaş/çevre/tanıdık yani sosyal normların güçlü bir etkisi olduğundan söz edilebilir. Bu sebeple turizm işletmelerinin olduğu kadar destinasyon yönetimlerinin de ağızdan ağıza pazarlama çalışmalarına önem vermesi gerekmektedir. Bunun için; sosyal medya kanallarını uzman bir kadro ile yönetmeli ve destinasyon hakkında gelen bütün yorumların iyi ya da kötü olduğuna bakılmaksızın hepsinin tek tek değerlendirilmesinin yapılması, cevaplanması gerekenlerin anında cevaplanması ya da bilgilendirme isteyenlerin yine vakit kaybetmeden bilgilendirilmelerinin yapilması gerekmektedir.

Antalya destinasyonunu tercih etme niyetinde tutumlar ise destinasyon tercih etme niyetini ikinci derecede etkileyen değişken olarak gözlenmiştir. Benzer şekilde Quintal ve arkadaşları (2010), Güney Koreli, Çinli ve Japon turistlerin seyahat öncesi niyetlerini PDT modeline göre araştırmış ve tutumun Japon turistlerin niyetleri üzerindeki etkisini olumlu bulurken Güney Koreli ve Çinli turistlerin niyetleri üzerinde herhangi bir etki bulamamıştır. Tutumların güçlendirilmesi ve niyeti daha fazla etkileyebilmesi adına destinasyonlarda, kurum ya da kuruluşlarda çeşitli etkinlikler düzenlenebilir. Y kuşağı turistlerine yönelik etkinlik ve kurs programları örneğin; tenis, okçuluk, yemek kursu, pastacılık eğitimi veya karaoke gecesi gibi etkinlikler düzenlenebilir. İnternet ve sosyal mecralarda oldukça yetkin olan Y kuşağı için hizmet kalitesi çoğu zaman otellerdeki kuvvetli internet erişimi (wireless) olmaktadır. Bu yüzden $Y$ kuşağ 1 turistlerine güçlü bir internet ağı, çevirimiçi sosyal kanallarında paylaşım yapabilecekleri farklı dizayn edilmiş alanlar sunmak, tutumlarını değiştirebilecek önemli detaydır. 
Algılanan davranış kontrolü, yerli Y kuşağı turistlerin Antalya destinasyonunu tercih etme niyetlerine en az etkiyi sağladığı gözlenmiştir. Akkuş (2013), çalışmasında; yemek amaçlı seyahat eden kişilerin niyetlerinde de algılanan davranış kontrolünün etkisini bulamamıştır. Yine, Alam ve Sayuti (2011) Malezya'daki tüketicilerin helal yiyecek satın alma niyetini incelerken algılanan davranış kontrolünün niyet üzerinde etkisine rastlamamıştır. Ayrıca, Hansen ve ark. (2004), arka arkaya yaptıkları çalışmalarında önce algılanan davranış kontrolünün, tüketicilerin internetten satın alma niyetlerinde etkili olmadığını daha sonraki çalışmalarında ise az da olsa bir etkisinin olduğunu tespit etmişlerdir. Bunun sebebi; turizm hareketlerinin çok önceden planlanmış ve bireylerin tüm şartlarının bu fikre göre ayarlanmış olmasından kaynaklanıyor olabilir. Çünkü turistik ürünlerin stoklanamaması ve ancak kendi yerlerinde satılabiliyor olması dikkate alınırsa, bireylerin bu satın alım için çok önceden zaman ve para ayırmaları mümkündür. Böylece çevrelerinde algıladıkları tehditleri en aza indirgeyebilecekleri düşünülebilir. Bu yüzden bu çalışmada da en az etkiyi algılanan davranış kontrolü vermiş olabilir.

\section{Kaynakça}

Akkuş, G. (2013). Yemek Turizmine Katılma Niyeti: Planlı Davranış Teorisi Çerçevesinde Bir İnceleme. Yayınlanmamış Yüksek Lisans Tezi, Erciyes Üniversitesi, Sosyal Bilimler Enstitüsü, Kayseri.

Alam, S.S, ve Sayuti, N. M. (2011). Applying the Theory of Planned Behavior in Halal Food Purchasing, International Journal of Commerce and Management. 21(1): 8-20.

Alonso, A.D., Sakellarios, N. ve Pritchard, M. (2015). The Theory of Planned Behaviour in the Context of Cultural Heritage Tourism, Journal of Heritage Tourism, 10(4): 399-416.

Ajzen, I., ve Fishbein, M. (1980). Understanding Attitudes and Predicting Social Behavior. Englewood Cliffs, NJ: Prentice-Hall.

Ajzen, I. (1985). From Intentions to Actions: A Theory of Planned Behavior. In J. Kuhl\& J. Beckman (Eds.), Action Control, From Cognition to Behaviour. Springer-Verlag Berlin Heidelberg.

Ajzen I. (1991). The Theory Of Planned Behaviour, Organizational Behaviour and Human Decision Processes. 50, Massaachussets.

Ajzen, I., (2008), Consumer Attitudes and Behavior, in C. P. Haugtvedt, P. M. Herr \& F. R. Cardes (Eds.), Handbook of Consumer Psychology, New York: Lawrence Erlbaum Associates.

Armitage, C. J., ve Christian, J. (2003). From Attitudes to Behaviour: Basic and Applied Research on the Theory of planned Behaviour. Current Psychology: Developmental, Learning, Personality, Social, 22: 187-195.

Baker, R. K., ve White, K. M. (2010). Predicting adolescents' use of social networking sites from an extended theory of planned behaviour perspective. Computers in Human Behavior, 26: 1591-1597.

Bozkurt, A.K. (2018). Planlanmış Davranış Teorisi Kapsamında Yerli Y Kuşağının Destinasyon Tercihlerinde Davranışsal Niyetlerinin Belirlenmesi (Antalya Örneği), Yayınlanmamış Doktora Tezi, Balıkesir Üniversitesi, Sosyal Bilimler Enstitüsü, Balıkesir.

Byrne, B. M. (1998). Structural equation modeling with lisrel, prelis and simlis: Basic concepts, aplications and programming. Mahwah, NJ: Lawrence Erlbaum Associates.

Çapık, C. (2014). Geçerlik ve Güvenirlik Çalışmalarında Doğrulayıcı Faktör Analizinin Kullanımı. Anadolu Hemşirelik ve Sağllk Bilimleri Dergisi, 17(3): 196-205. 
Çepni, Z. (2010). Yapısal Eşitlik Modellemesi PPT Sunumu, Web: http://yunus.hacettepe.edu.tr/ cepni/mersinsemsunu.ppt. (Erişim tarihi: 16.04.2018).

De Cannière, M.H., De Pelsmacker, P. and Geuens, M. (2009), Relationship Quality and the Theoryof Planned Behavior Models of Behavioral İntentions and Purchase Behavior, Journal of Business Research, 62(1): 82-92.

De Vaus, D.A. (1990). Survey in Social Research (2. Basım), London: Unwin Hyman.

Erciş, A. ve Ünal, S. (2009). Gençlerin Kişisel Değerleri İle Satın Alma Tarzları Arasındaki İlişkilerin Belirlenmesi, Pazarlama ve Pazarlama Araştırmaları Dergisi, 4: 19-44.

Erten, S. (2002). Planlanmış Davranış Teorisi İle Uygulamalı Ders İşleme Öğretim Metodu, Hacettepe Üniversitesi Edebiyat Fakültesi, 19 (2): 217-233.

Etlican, G. (2012). X ve Y Kuşaklarının Online Eğitim Teknolojilerine Karşı Tutumlarının Karşılaş̧tırllması, Yayınlanmamış Yüksek Lisans Tezi, Bahçeşehir Üniversitesi Sosyal Bilimler Enstitüsü, İstanbul.

Foster, P.J. ve Fullagar, C.J (2018). Why Don't We Report Sexual Harassment? An Application of the Theory of Planned Behavior, Basic and Applied Social Psychology 40(3):1-13.

Güzeller, C. (2006). Ortaöğretim Kurumları Öğrenci Seçme Sınavının Türkçe Dil Yeterlilikleri Açısından Modellenmesi, Kastamonu Eğitim Dergisi, 14(2): 403-412.

Hammill, G. (2005). Mixing and Managing Four Generations of Employees. FDU Magazine Online. web: http://www.fdu.edu/newspubs/magazine/05ws/generations.htm, (Erişim tarihi: 04.12.2017).

Han, H., Hsu, L. T. J. ve Sheu, C. (2010). Application of the Theory of Planned Behavior to Green Hotel Choice: Testing the Effect of Environmental Friendly Activities, Tourism Management, 31(3): 325-334.

Han, H., \& Kim, Y. (2010). An Investigation of Green Hotel Customers' Decision Formation: Developing an Extended Model of the Theory of Planned Behavior, International Journal of Hospitality Management, 29(4): 659-668.

Hansen, T., Jensen, J. M., Solgaard, H. S., (2004), Predicting Online Grocery Buying Intention: A Comparison of the Theory of Reasoned Action and the Theory of Planned Behavior, International Journal of Information Management, 24: 539-550.

Hudson, S., Thal, K., Cárdenas, D. ve Meng, F. (2017). Wellness Tourism: Stress Alleviation or İndulging Healthful Habits?. International Journal of Culture, Tourism and Hospitality Research, 11 (1): 35-52.

İnceoğlu, M. (2010). Tutum, Algı, Illetişim. 5. Baskr. İstanbul: Beykent Üniversitesi Yayınları, No: 69.

Jalilvand, M. R., ve Samiei, N. (2012). The impact of electronic word of mouth on a tourism destination choice: Testing the theory of planned behavior (TPB), Internet research, 22(5): 591-612.

Kağıtçıbaşı, Ç. ve Cemalcılar, Z. (2015). Dünden Bugüne İnsan ve İnsanlar, Sosyal Psikolojiye Giriş, 17. Basım, İstanbul: Evrim Yayınevi.

Kim, S.H., Kim, S., Huh, C. and Knutson, B. (2010), "A predictive model of behavioral intention to spa visiting: an extended theory of planned behavior", web erişim: http://scholarworks.umass.edu/cgi, (Erişim tarihi:25.09.2018). 
Kocagöz, E., ve Dursun, Y. (2010). Algılanan Davranışsal Kontrol, Ajzen'in Teorisinde Nasıl Konumlanır? Alternatif Model Analizleri, KMÜ Sosyal ve Ekonomik Araştırmalar Dergisi, 12 (19): 139-152.

Kolvereid, L. (1997), Prediction of employment status choice intentions. Entrepreneurship Theory \& Practice, 21: 47-57.

Lai, C., Yu, PhD, T., \& Kuo, J. (2010). How to say sorry: Increasing revisit intention through effective service recovery in theme parks, Social Behavior and Personality: An international journal, 38: 509-514.

Lam, T. and Hsu, C. (2006). Predicting Behavioral İntention of Choosing a Travel Destination, Tourism Management, 27(2): 589-599.

Lin, N. (1976). Foundations of Social Research, New York: McGraw-Hill.

Luarn, P. ve Lin. H-H. (2005). Toward an understanding of the behavioral intention to use mobile banking, Computers in Human Behavior, 21: 873-891.

Marsh, H.W., Hocevar, D. (1988). A New More Powerful Approach to Multitrait-Multimethod Analyses: Application of Second-Order Confirmatory Factor Analysis, Journal of Applied Psychology, (73): 107-117.

Martin, D.S., Ramamonjiarivelo, Z. and Martin, W. (2011) 'MEDTOUR: a Scale for Measuring Medical Tourism Intentions', The Tourism Review, 66(1/2): 45-56.

Middleton, C. ve Smith, S. (2011). Purchasing Habits of Senior Farmers' Market Shoppers: Utilizing the Theory of Planned Behavior. Journal of Nutrition in Gerontology and Geriatrics, 30: $248-260$.

Mullan, B., ve Wong, C. (2010). Using the Theory of Planned Behaviour to design a food hygiene intervention, Food Control, 21: $1524-1529$.

Netemeyer, R.G., Andrews, J.C. ve Durvasula, S. (1993). A Comparison Of Three Behavioral Intention Models: The Case Of Valentine's Day Gift-Giving. Advances in Consumer Research, 20: $135-141$.

Özen, Y ve Gül. A. (2007). Sosyal ve Egitim Bilimleri Araştırmalarında Evren-Örneklem Sorunu, KKEFDI/OKKEF, 15: 394-422.

Pendergast, D. (2010) Getting to Know the Y Generation. Eds: Benckendorff, P., Moscardo, G., Pendergast, D., in Tourism and Generation Y, Cambridge: CAB International.

Perugini, M. ve Bagozzi, R. (2001). The Role of Desires and Anticipated Emotions in GoalDirected Behaviors. Broadening and Deepening the Theory of Planned Behavior, British Journal of Social Psychology, 40 (1): 79-98.

Quintal, V. A., Lee, J. A., ve Soutar, G. N. (2010). Risk, Uncertainty and the Theory of Planned Behavior: A Tourism Example, Tourism Management, 31(6): 797- 805.

Reddy, S., York, V.K., \& Brannon, L.A. (2010). Travel for Treatment: Students' Perspective on Medical Tourism. International Journal of Tourism Research, 12(5): 510-522.

Ryu, K., Han, H. (2010).Predicting Tourists' İntention to Try Local Cuisine Using a Modified Theory of Reasoned Action: the Case of New Orleans. J. Travel Tourism Market. 27(5): 491506.

Schubert, F., Kandampully, J., Solnet, D. ve Kralj, A. (2010), Exploring Consumer Perceptions of Green Restaurants in the US, Tourism and Hospitality Research, 10(4): 286-300. 
Schultz, J.R. (2014). Applying The Theory of Planned Behavior to Participation in Sustainable Tourism Certification Programs, Unpublished Doctor of Philosophy, The University of Utah, United States.

Shaw, D. ve Shiu, E. (2002). Ethical obligation and self-identity in consumer choice, International Journal of Consumer Studies, 26(2): 109-116.

Sparks, B. ve Pan, G.W. (2009). Chinese Outbound tourists: Understanding their Attitudes, Constraints and use of İnformation Sources, Tourism Management, 30: 483-494.

Taşkın, Ç. ve Akat, Ö. (2010). Araştırma Yöntemlerinde Yapısal Eşitlik Modelleme, Bursa: Ekin Basım Yayın Dağıtım.

Tkachev, A. ve Kolvereid, L. (1999). Self-employment İntentions Among Russian Students. Entrepreneurshıp \& Regional Development, 11: 269-280.

Tutar, H. (2015). Davranış Bilimleri, Kavramlar ve Kuramlar, 2. Bask1. Ankara: Seçkin Yayıncilik.

Tüik, (2013), Seçilmiş Göstergelerle Antalya 2013, Ankara: Türkiye İstatistik Kurumu Matbaas1.

Türk, A. (2014). Y Kuşağı, İstanbul: Kafekültür Yayıncılık.

Usluel Y. K. ve Mazman S. G. (2010). Eğitimde Yeniliklerin Yayılımı, Kabulü ve Benimsenmesi Sürecinde Yer Alan Öğeler: Bir İçerik Analizi Çalışması, Çukurova Üniversitesi Eğitim Fakültesi Dergisi, 3(39): 60-74.

Vargas-Sánchez, A., Plaza-Mejía, M.A. ve Porras-Bueno, N. (2015). “Attitude, tourism”, (eds.) in Jafar Jafari and Honggen Xiao, Encyclopedia of Tourism. 2nd ed,. London: Springer International Publishing.

Wang, C., Zhang, J., Yu, P. ve Hu, H. (2018). The theory of planned behavior as a model for understanding tourists' responsible environmental behaviors: The moderating role of environmental interpretations, Journal of Cleaner Production, 194(1): 425-434.

Wang, J. (2012). Wiley Series in Probability and Statistics, Structural Equation Modeling with MPlus: Methods and Applications (3rd Edition). Somerset, NJ, USA: John Wiley \& Sons Press.

Yamada, N. ve Fu, Y. (2012). Using the Theory Of Planned Behavior to Identify Beliefs Underlying Visiting the Indiana State Museum, Journal of Travel \& Tourism Marketing, 29: 119-132. 